CLINICAL STUDY

\title{
Similar prevalence of somatic TSH receptor and Gs $\alpha$ mutations in toxic thyroid nodules in geographical regions with different iodine supply in Turkey
}

\author{
Hulya Ilıssu Gozu ${ }^{1, *}$, Rifat Bircan ${ }^{4, *}$, Knut Krohn $^{5}$, Sandra Müller ${ }^{6}$, Selahattin Vural ${ }^{2}$, Cem Gezen $^{2}$, Haluk Sargin ${ }^{1}$, \\ Dilek Yavuzer $^{3}$, Mehmet Sargin ${ }^{1}$, Beyazit Cirakoglu ${ }^{4}$ and Ralf Paschke ${ }^{6}$ \\ ${ }^{1}$ Section of Endocrinology and Metabolism and Departments of ${ }^{2}$ General Surgery and ${ }^{3}$ Pathology, Dr. Lutfi Kirdar Kartal Education and Research \\ Hospital, 34865 Istanbul, Turkey, ${ }^{4}$ Department of Medical Biology, Marmara University Medical School, 34668 Istanbul, Turkey, and ${ }^{5}$ Interdisciplinary \\ Center of Clinical Research and ${ }^{6}$ Department of Internal Medicine III, University of Leipzig, D-04103 Leipzig, Germany \\ (Correspondence should be addressed to R Paschke; Email: pasr@medizin.uni-leipzig.de) \\ *(H I Gozu and R Bircan contributed equally to this work)
}

\begin{abstract}
Objective: Differences in iodine intake could account for the variable prevalences reported for somatic TSH receptor (TSHR) mutations in toxic thyroid nodules (TTNs). However, this question has not been settled, since no study has yet determined the TSHR mutation prevalence in regions with different iodine supplies in the same population using the same methodology. Therefore, we studied the prevalence of somatic TSHR mutations in TTNs from patients living in iodine-deficient or -sufficient regions in Turkey.

Design and methods: We screened 74 TTNs for somatic TSHR mutations. Exons 9 and 10 of the TSHR and 7 and 8 of the Gs $\alpha$ were screened by denaturing gradient gel electrophoresis. Determination of X-chromosome inactivation was used for clonality analysis.

Results: TSHR mutations were identified in 52 (70.2\%) of 74 TTNs. A Gs $\alpha$ mutation was identified in one TTN. Three new TSHR mutations were detected (A627V, I640K, I486N). No significant difference between frequencies of TSHR mutations in iodine deficient/sufficient regions was found. The frequency of non-random X-chromosome inactivation was similar in iodine-sufficient or -deficient regions and in TSHR mutation positive or negative hot nodules.

Conclusions: These findings suggest that TTNs in iodine deficient/sufficient areas predominantly arise from aberrant growth of a single cell. Our results suggest that neither the prevalence of TSHR mutations nor that of monoclonal TTNs is related to iodine supply.
\end{abstract}

European Journal of Endocrinology 155 535-545

\section{Introduction}

Constitutive activation of the cAMP cascade caused by a somatic thyroid-stimulating hormone receptor (TSHR) mutation results in increased growth and function of the thyroid follicular cells that cause autonomously functioning thyroid tissue $(1,2)$, which is characterized by its capacity to grow and function independent of the serum levels of thyroid hormones and TSH. Autonomy can present in different histological forms, such as adenoma or adenomatous nodule, but rarely as malignant thyroid epithelial tumors with hyperthyroidism or as microscopic hot areas in euthyroid goiters (2). Thyroid autonomy occurs mostly in toxic multinodular goiters (TMNGs) (2), which is the most frequent cause of thyrotoxicosis in the elderly, especially in iodinedeficient areas (3). In iodine-deficient regions, TMNG and toxic adenoma (TA) account for 50 and $10 \%$ of cases with thyrotoxicosis respectively. On the other hand, in iodine-sufficient areas, thyroid autonomies account only for $3-10 \%$ of cases with hyperthyroidism (3). Moreover, the prevalence of thyroid autonomy decreases after the eradication of iodine deficiency (1).

The frequency of somatic mutations in toxic thyroid nodules (TTNs) varies between 8 and $82 \%$ for TSHR (1, see TSH Receptor Mutation Database II, http://www. uni-leipzig.de/ innere and Table 1 (4-25)), and between 3 and $38 \%$ for Gs $\alpha(5,19)$ in different reports. In particular, studies from Japan with a very high iodine supply have reported distinctly lower frequencies for TSHR mutations in hot nodules $(10,20)$. Therefore, it has been proposed that apart from differing methodology, differences in iodine intake could account for the variable prevalence of these mutations in different studies (Table 1) (4-25). Although this hypothesis has been questioned recently (20), this study only investigated ten Japanese patients. Therefore, the question whether iodine does influence the prevalence of the 
Table 1 Prevalences of the thyroid stimulating hormone receptor (TSHR) and Gs $\alpha$ mutations in studies from different countries in relation to detection methodology and iodine status.

\begin{tabular}{|c|c|c|c|c|c|c|c|c|c|}
\hline $\begin{array}{l}\text { Year of the } \\
\text { TSHR mutation } \\
\text { analysis } \\
\text { (references) }\end{array}$ & From & $\begin{array}{l}\text { Median UI }(\mu \mathrm{g} / \mathrm{l}) \\
\quad \text { (references) }\end{array}$ & $\begin{array}{l}\text { Number of } \\
\text { TTNs }\end{array}$ & Method & $\begin{array}{l}\text { Type of } \\
\text { tissue } \\
\text { samples }\end{array}$ & $\begin{array}{l}\text { TSHR region } \\
\text { examined }\end{array}$ & $\begin{array}{l}\text { TSHR mutation } \\
\text { frequency }\end{array}$ & $\begin{array}{l}\text { Gs } \alpha \text {-region } \\
\text { examined }\end{array}$ & $\begin{array}{l}\text { Gs } \alpha \\
\text { mutation } \\
\text { frequency }\end{array}$ \\
\hline $1990(4)$ & USA & $145(23)$ & 4 & ASO & FFT or PEB & Not studied & & Codon $201+227$ & $(25 \%)$ \\
\hline $1991(5)$ & UK & $141(24)$ & 13 & ASO & PEB & Not studied & & Codon $201+227$ & $5 / 13(38 \%)$ \\
\hline $1993(6)$ & Belgium & $80(23,24)$ & 11 & Sequencing & FFT & $\begin{array}{l}\text { ICL3, Residues } \\
\text { 589- }\end{array}$ & $3 / 11(27 \%)$ & Not studied & \\
\hline $1994(7)$ & Italy & $55-142(23,24)$ & 11 & $\begin{array}{l}\text { Restriction, } \\
\text { Sequencing }\end{array}$ & FNAB & TM5-C Term. & $7 / 11(64 \%)$ & Not studied & \\
\hline $1994(8)$ & Germany, Italy & & 9 & Sequencing & FFT & TM5-C Term. & 2/9 (22\%) & Not studied & \\
\hline $1995(9)$ & Italy & $55-142(23,24)$ & 37 & ASO, Sequencing & FFT & $\begin{array}{l}\text { ICL } 1,2,3 \text { and } C \\
\text { Term. }\end{array}$ & $3 / 37(8 \%)$ & Exons 8 and 9 & 9/37 (24\%) \\
\hline 1995 (10) & Japan & $296-728(25)$ & 45 & SSCP & PEB & TM6 and ICL 3 & $0 / 45$ & Not studied & \\
\hline 1996 (11) & Italy & $55-142(23,24)$ & 44 & Sequencing & FFT & Exon 10 & 9/44 (20\%) & Not studied & \\
\hline $1997(12)$ & Belgium & $80(23,24)$ & 33 & Sequencing & FFT & $\begin{array}{l}\text { Entire coding } \\
\text { region }\end{array}$ & $27 / 33(82 \%)$ & Exons 8 and 9 & $2 / 33(6 \%)$ \\
\hline $1997(13)$ & Germany & $88-148(23,24)$ & 31 & ASP, Sequencing & FFT & Exons 9 and 10 & $15 / 31(48 \%)$ & Exons 7-10 & $0 / 31$ \\
\hline 1997 (14) & Germany & $88-148(23,24)$ & 13 (inTMNG) & Sequencing & FFT & Exons 9 and 10 & $5 / 13(38 \%)$ & Exons 7-10 & $0 / 13$ \\
\hline $1998(15)$ & Italy & $55-142(23,24)$ & 17 & Sequencing & FFT & Exon 10 & $\begin{array}{l}\text { TMNG } 5 / 6 \\
(83 \%), \text { TA } \\
8 / 11(72 \%)\end{array}$ & Not studied & \\
\hline $1999(16)$ & Italy & $55-142(23,24)$ & 38 & $\begin{array}{l}\text { Restriction, } \\
\text { Sequencing }\end{array}$ & FNAB & ICL 3, entire TM & $6 / 38(16 \%)$ & Not studied & \\
\hline $2000(17)$ & Germany & $88-148(23,24)$ & $\begin{array}{l}37 \text { hot areas } \\
\text { in } 14 \\
\text { patients }\end{array}$ & Sequencing & PEB & $\begin{array}{l}\text { A part of exon } 10 \\
\text { (482-677 a.a) }\end{array}$ & $\begin{array}{c}\text { In hot areas } 4 / 37 \\
(18 \%), \text { in the } \\
\text { patients } 4 / 14 \\
(28.5 \%)\end{array}$ & Not Studied & \\
\hline $2000(18)$ & Italy & $55-142(23,24)$ & 20 (in TMNG) & Sequencing & FFT & Exons 9 and 10 & $14 / 20(70 \%)$ & Exons 8 and 9 & $0 / 20$ \\
\hline 2001 (19) & Germany & $88-148(23,24)$ & 75 & DGGE, Sequencing & FFT & Exons 9 and 10 & $43 / 75(57 \%)$ & Exons 7 and 9 & 2/75 (3\%) \\
\hline 2002 (20) & Japan & $296-728(25)$ & 10 & Sequencing & FFT & $\begin{array}{l}\text { Entire TSHR } \\
\text { coding region }\end{array}$ & $4 / 10(40 \%)$ & Exons 2-13 & $1 / 10(10 \%)$ \\
\hline $2003(21)$ & Greece & $84-160$ (24) & 28 & Sequencing & FFT & Exons 9 and 10 & $11 / 28(40 \%)$ & Exons 7-10 & $1 / 28(4 \%)$ \\
\hline 2005 (22) & Turkey & $36(23)$ & 58 & SSCP & FFT & $\begin{array}{l}\text { A part of exon } 10 \\
(482-677 \text { a.a) }\end{array}$ & $10 / 58(17 \%)$ & Exons 8-9 & $0 / 58$ \\
\hline
\end{tabular}


TSHR mutations has not been settled, since large numbers of TTNs have so far been investigated only in very few geographic regions with similar iodine status (e.g. Belgium, Italy, Germany, and Greece) (Table 1) (9, $11-13,16,19,21)$. However, it is not possible to perform the gold standard study which determines the TSHR mutation prevalence in hot nodules with the same methodology for patients of the same population with a clearly documented lifelong exposure to iodine deficiency or normal iodine status. Therefore, to investigate whether the TSHR mutation prevalence is influenced by the degree of iodine deficiency, we determined and compared the prevalence of somatic TSHR mutations in different geographical regions of Turkey with marked differences in iodine supply documented 3-5 years ago. The significant relation between the iodine status and the socioeconomic differences, and the persistence of these differences in the past, makes it highly likely that these differences in iodine supply existed throughout the lifetime of the investigated patients.

\section{Materials and methods}

\section{Patients}

The present study was approved by the Marmara University Ethics Committee and informed consent was obtained from all patients before surgery.

A total of 74 consecutive TTNs and their surrounding tissues (if not available, peripheral blood samples) were obtained from 56 unrelated patients who underwent subtotal thyroidectomy. One or two hot nodules were found in 38 and 18 of the 56 patients respectively. The mean age of the patients (45 female and 11 male) was $51.5 \pm 11.7$; range, $24-75$ years. Histopathology showed nodular hyperplasia (goiter) in all patients. These patients have not been reported previously.

At the time of diagnosis, 53 patients were clinically thyrotoxic. They were treated with propylthiouracil and $\beta$-blocker drugs preoperatively. The other three patients who underwent surgical treatment had normal free triiodothyronine $\left(\mathrm{T}_{3}\right)$ and free thyroxine $\left(\mathrm{T}_{4}\right)$ and suppressed TSH values. Toxic multi- or uninodular goiter was diagnosed on the basis of clinical thyrotoxicosis, thyroid function tests (high $\mathrm{T}_{4}$ and/or $\mathrm{T}_{3}$, and suppressed TSH), thyroid sonography, histopathological examination, and thyroid scintigraphic images associated with predominant $\mathrm{Tc}^{99 \mathrm{~m}}$ uptake in one (or more) nodule (nodules) with the suppression of surrounding thyroid tissue.

Nodules defined by scintigraphy and ultrasonography (US) were unequivocally identified intraoperatively. In each case, a map that depicts the nodules as they appeared on the scan in ultrasound and during surgery was drawn. Samples from the center of TTNs, peripheral normal tissues, and blood samples were taken. Tissue specimens were frozen in liquid nitrogen. The demographic characteristics of the patients are shown in Table 2. In this study, iodine-deficient and sufficient regions were defined as those where the median urinary iodine (UI) secretion was previously determined as $<100 \mu \mathrm{g} / \mathrm{l}(26-31)$. The places of birth of the patients and their areas of residency in Turkey were recorded. We also classified a mixed group because some patients partially lived in both iodine-deficient and -sufficient regions. Istanbul and the region of Kocaeli have been identified as iodine sufficient by representative determinations of the median UI of school children performed by three studies in 1999, 1995, and 1999 respectively (Gür et al., Akpınar et al., and Beykal et al.) (27-29). Erdogan et al. investigated the UI and goiter prevalence of 5948 school children living in various cities of Turkey. This study was performed from 1997 to 1999 and classified Kastamonu, Bayburt, Trabzon, Erzurum, Malatya, Samsun, Edirne, Aydın, Kayseri, Ankara, Burdur, Isparta, Erzincan, Konya, Van, Diyarbakır, Çorum, Bolu, Kütahya, and Bursa as iodine deficient and endemic goiter regions (26). Further, iodine deficient cities in Turkey were identified by UI determination of school-aged children by other studies (30-31). Since the representative study by Gür et al., identified significant associations of iodine deficiency with socioeconomic variables (27) and because it is known that large socioeconomic differences between Istanbul, Kocaeli and the iodine deficient regions were also present in the past, it is most likely that similar differences in iodine supply which have been documented by the studies described earlier were also present in the past. This assumption is also consistent with an earlier report (32) characterizing Istanbul and Kocaeli as cities with the lowest risk of endemic goiter.

Patients who lived in areas for which UI concentrations cannot be defined on the basis of published results were classified according to the reported occurrence or absence of endemic goiter for these areas. This classification is based on the published prevalence of goiters in the respective areas of residence as detected by palpation (32). The patients classified as iodine deficient on the basis of the reported occurrence of endemic goiters in their areas of residency from 1980 to 1987 are labeled as iodine deficient GP' in Table 2. Goiter prevalence is an accepted indicator of iodine deficiency (33). To clearly state the different evidences for iodine deficiency, the iodine-deficient patients were classified into two groups: iodine deficient by UI excretion (iodine deficient UI) and iodine deficient by endemic goiter prevalence (iodine deficient GP). The iodine-deficient patients determined by UI excretion and those classified iodine deficient by the occurrence of endemic goiters in their areas of residency, were compared as two separate groups with the patients living in iodine-sufficient or mixed regions. 
Table 2 Demographic and clinical characteristics of the patients.

\begin{tabular}{|c|c|c|c|c|c|}
\hline No. & Age & Gender & TSHR mutation & $\begin{array}{l}\text { D727E } \\
\text { polymorphism }\end{array}$ & Clonality \\
\hline \multicolumn{6}{|c|}{ Iodine deficient $\mathrm{UI}$ according to references $(26,30,31)^{\mathrm{a}}$} \\
\hline 1 & 65 & $\mathrm{~F}$ & D633Y & Positive & Clonal \\
\hline 6 & 43 & $\mathrm{~F}$ & Negative & Negative & Not informative \\
\hline 15 & 41 & $\mathrm{~F}$ & V656F & Negative & Clonal \\
\hline \multirow[t]{2}{*}{18} & 45 & $\mathrm{~F}$ & M453T & Positive & Not informative \\
\hline & & & T632I & Positive & Not informative \\
\hline \multirow[t]{2}{*}{24} & 72 & $\mathrm{~F}$ & T632I & Negative & Not informative \\
\hline & & & L629F & Negative & Clonal \\
\hline 36 & 43 & $\mathrm{~F}$ & L629F & Negative & Clonal \\
\hline \multirow[t]{2}{*}{39} & 47 & $\mathrm{~F}$ & Negative & Negative & Polyclonal \\
\hline & & & Negative & Negative & Polyclonal \\
\hline 40 & 60 & $\mathrm{~F}$ & P639S & Negative & Clonal \\
\hline 43 & 35 & $\mathrm{~F}$ & Negative & Negative & Clonal \\
\hline 45 & 26 & $\mathrm{~F}$ & I568T & Negative & Clonal \\
\hline $49^{\mathrm{b}}$ & 42 & $\mathrm{~F}$ & Negative & Positive & Clonal \\
\hline \multirow[t]{2}{*}{51} & 56 & $\mathrm{~F}$ & $1630 \mathrm{~L}$ & Negative & Clonal \\
\hline & & & A627V & Negative & Clonal \\
\hline 57 & 65 & $\mathrm{~F}$ & Negative & Negative & Clonal \\
\hline \multirow[t]{2}{*}{61} & 35 & $\mathrm{~F}$ & Negative & Negative & Not informative \\
\hline & & & L512R & Negative & Not informative \\
\hline 62. & 24 & $\mathrm{~F}$ & F631L & Negative & Clonal \\
\hline \multicolumn{6}{|c|}{ Iodine deficient GP according to reference $(32)^{\mathrm{C}}$} \\
\hline 2 & 37 & $\mathrm{~F}$ & D633Y & Negative & Clonal \\
\hline \multirow[t]{2}{*}{7} & 54 & $\mathrm{~F}$ & Negative & Negative & Not informative \\
\hline & & & Negative & Negative & Not informative \\
\hline 9 & 72 & $\mathrm{M}$ & Negative & Negative & Male \\
\hline 12 & 45 & $\mathrm{~F}$ & M453T & Negative & Clonal \\
\hline 16 & 52 & $\mathrm{~F}$ & L512Q & Negative & Polyclonal \\
\hline 19 & 50 & $\mathrm{~F}$ & T632A & Positive & Clonal \\
\hline 27 & 43 & $M$ & F631L & Negative & Male \\
\hline 29 & 64 & $M$ & T632I & Negative & Male \\
\hline 31 & 54 & $\mathrm{~F}$ & T632A & Negative & Clonal \\
\hline 42 & 48 & $\mathrm{~F}$ & M453T & Negative & Polyclonal \\
\hline 48 & 59 & $\mathrm{~F}$ & Negative & Negative & Clonal \\
\hline \multirow[t]{2}{*}{52} & 44 & $\mathrm{~F}$ & A428V & Negative & Clonal \\
\hline & & & Negative & Negative & Clonal \\
\hline \multicolumn{6}{|c|}{ Iodine sufficient according to references (27-29) } \\
\hline 3 & 58 & $\mathrm{~F}$ & Negative & Negative & Clonal \\
\hline \multirow[t]{2}{*}{5} & 62 & $M$ & T632I & Negative & Male \\
\hline & & & A623V & Negative & Male \\
\hline \multirow[t]{2}{*}{10} & 54 & $\mathrm{~F}$ & D619G & Negative & Polyclonal \\
\hline & & & D619G & Negative & Clonal \\
\hline \multirow[t]{2}{*}{17} & 31 & $\mathrm{~F}$ & T632I & Positive & Clonal \\
\hline & & & L512Q & Positive & Clonal \\
\hline 22 & 38 & $\mathrm{~F}$ & Negative & Positive & Polyclonal \\
\hline & & & $1486 \mathrm{~F}$ & Positive & Polyclonal \\
\hline 25 & 43 & $\mathrm{~F}$ & D633Y & Positive & Not informative \\
\hline 26 & 37 & $\mathrm{~F}$ & D619G & Negative & Clonal \\
\hline 28 & 48 & $\mathrm{~F}$ & T632I & Negative & Not informative \\
\hline 30 & 57 & M & Negative & Negative & Male \\
\hline 33 & 53 & $\mathrm{~F}$ & S505N & Negative & Clonal \\
\hline 34 & 75 & $\mathrm{~F}$ & A623V & Negative & Clonal \\
\hline 38 & 60 & $\mathrm{~F}$ & A623V & Negative & Not informative \\
\hline 41 & 72 & $\mathrm{~F}$ & Negative & Negative & Clonal \\
\hline & & & Negative & Negative & Clonal \\
\hline 47 & 42 & M & $\mathrm{D} 633 \mathrm{H}$ & Negative & Male \\
\hline Mix & $(26-3$ & & & & \\
\hline 8 & 58 & M & Negative & Negative & Male \\
\hline & & & Negative & Negative & Male \\
\hline 11 & 71 & $\mathrm{~F}$ & D619G & Positive & Clonal \\
\hline 20 & 54 & $\mathrm{~F}$ & Negative & Negative & Clonal \\
\hline & & & M453T & Negative & Polyclonal \\
\hline 21 & 48 & $\mathrm{~F}$ & M453T & Negative & Clonal \\
\hline & & & L629F & Negative & Clonal \\
\hline 23 & 66 & $\mathrm{M}$ & $1486 \mathrm{~N}$ & Negative & Male \\
\hline
\end{tabular}




\begin{tabular}{|c|c|c|c|c|c|}
\hline No. & Age & Gender & TSHR mutation & $\begin{array}{l}\text { D727E } \\
\text { polymorphism }\end{array}$ & Clonality \\
\hline & & & l486F & Negative & Male \\
\hline 35 & 41 & $\mathrm{~F}$ & T632I & Negative & Clonal \\
\hline \multirow[t]{2}{*}{44} & 50 & $M$ & I640K & Negative & Male \\
\hline & & & A428V & Negative & Male \\
\hline 46 & 47 & $\mathrm{~F}$ & Negative & Positive & Polyclonal \\
\hline 50 & 43 & $\mathrm{~F}$ & M453T & Negative & Polyclonal \\
\hline 53 & 53 & $M$ & $\mathrm{~S} 281 \mathrm{~N}$ & Negative & Male \\
\hline 54 & 55 & $\mathrm{~F}$ & D619G & Positive & Polyclonal \\
\hline 55 & 51 & $\mathrm{~F}$ & T632I & Negative & Clonal \\
\hline 56 & 60 & $M$ & Negative & Positive & Male \\
\hline 60 & 52 & $\mathrm{~F}$ & $\mathrm{~S} 281 \mathrm{~N}$ & Negative & Polyclonal \\
\hline
\end{tabular}

A total of 74 consecutive toxic thyroid nodules (TTNs) were obtained from 56 unrelated patients who underwent thyroidectomy.

${ }^{a}$ Iodine deficient $\mathrm{UI}$, iodine deficient by urinary iodine excretion. ${ }^{\mathrm{b}} \mathrm{G} s \alpha$ mutation $(\mathrm{R} 201 \mathrm{H})$ has been detected in only one patient. ${ }^{\mathrm{c}}$ lodine deficient GP, iodine deficient by endemic goiter prevalence.

DNA isolation Genomic DNA was isolated from frozentissue specimens using standard techniques as described previously by Krohn et al. (17). Genomic DNA from lymphocytes was isolated using a standard phenolchloroform methodology.

PCR, denaturing gradient gel electrophoresis (DGGE) and sequencing of TSHR gene In order to investigate the TSHR sequence for mutations in exons 9 and 10 of the TSHR gene, PCR, DGGE, and sequencing analysis were performed as described by Trülzsch et al. (19). The PCR products in which mutations were detected in exons 9 and 10 of the TSHR gene by DGGE were sequenced using Big Dye-terminator chemistry (Applied Biosystems, Germany) according to the manufacturer's instructions and analyzed on an automatic sequencer ABI 310 (Applied Biosystems, Germany).

PCR and sequencing of Gs $\boldsymbol{\alpha}$ DNA samples without TSHR gene mutations were analyzed for known Gs $\alpha$ mutations in exons 7 and 8. PCR and sequencing reactions were performed as described earlier using the following primers: sense $5^{\prime}$ AGTTGGCAAATTGATGTGAGC $3^{\prime}$ and antisense $5^{\prime}$ TCTCTATAAACAGTGCAGACC $3^{\prime}$.

Clonality and quantification of $X$-chromosome inactivation Clonality was determined and analyzed as described by Krohn et al. (34).

Total RNA extraction Total RNA of the tissue sample carrying a new mutation was isolated from frozentissue specimens using TRIZol reagent (Life technologies, USA) according to the manufacturer's manual. Later, the total RNA was purified with the
RNeasy kit (Qiagen, Germany) according to the manufacturer's protocol.

Cloning of new TSHR mutations Mutations I486N, A428V, A627V, and I640K were introduced into the human TSHR via site-directed mutagenesis. Human TSHR-pSVL was used as a template. PCR products containing the mutations were digested with the restriction enzymes (MBI Fermantas) BspTI and Eco91I (I486N and A428V) or Eco81I and Eco91I (A627V and I640K). The obtained fragments were used to replace the corresponding part in the wild-type (wt) TSHR-pSVL vector. Mutated TSHR sequences were verified by dideoxy sequencing as described earlier.

Cell culture and transient expression of mutant TSHR COS-7 cells were grown in Dulbecco's modified Eagle's medium (DMEM) supplemented with 10\% fetal calf serum, $100 \mathrm{U} / \mathrm{ml}$ penicillin, and $100 \mu \mathrm{g} / \mathrm{ml}$ streptomycin (Gibco Life technologies) at $37^{\circ} \mathrm{C}$ in a humidified $5 \% \mathrm{CO}_{2}$ incubator. Cells were transiently transfected using the GeneJammer Transfection reagent (Stratagene, NL). For determination of cAMP, accumulation cells were transfected in 24 -well plates $\left(0.5 \times 10^{5}\right.$ cells per well) with $0.5 \mu \mathrm{g}$ DNA per well. For FACS analysis, cells were transfected in 12 -well plates $\left(1 \times 10^{5}\right.$ cells per well) with $1 \mu \mathrm{g}$ DNA per well.

CAMP accumulation assay Activation of cAMP cascade was performed $48 \mathrm{~h}$ after transfection. Cells were preincubated with serum-free DMEM without antibiotics containing $1 \mathrm{mM}$ 3-isobutyl-1-methylxanthine (IBMX) (Sigma Chemical Co., USA) for $30 \mathrm{~min}$ at $37^{\circ} \mathrm{C}$ in a humidified $5 \% \mathrm{CO}_{2}$ incubator. Subsequently, cells were stimulated in the same medium supplemented with $100 \mathrm{mU} / \mathrm{ml}$ bTSH (Sigma Chemical Co.) for $1 \mathrm{~h}$. 
Reactions were terminated by aspiration of the medium. The cells were washed once with ice-cold PBS and lyzed by the addition of $0.1 \mathrm{~N} \mathrm{HCl}$ (equivalent to $0.1 \mathrm{M}$ ). The supernatants were collected and dried. cAMP content of the cell extracts was determined using the cAMP AlphaScreen assay (PerkinElmer Life Sciences, Belgium) according to the manufacturer's instructions. Basal cAMP accumulation of wtTSHR was set at 1 and results of the mutants (basal and stimulated cAMP content) were calculated according to this.

Effect of TSHR expression on basal cAMP accumuIation (linear regression analysis of constitutive activity as a function of TSHR expression) COS-7 cells were transiently transfected in 24-well plates $\left(0.5 \times 10^{5}\right.$ cells per well) with six concentrations of weightand TSHR constructs (50, 100, 150, 200, 250, and 300 ng DNA per well) for radioligand binding and in parallel for the cAMP accumulation assay. For radioligand binding assays, cells were incubated for $4 \mathrm{~h}$ at room temperature in the presence of 180.000200.000 c.p.m. of ${ }^{125}$ I-bTSH supplemented with $5 \mathrm{mU} / \mathrm{ml}$ non-labeled bTSH. The effect of expression level on basal cAMP accumulation was analyzed using the results for TSH binding and basal cAMP accumulation obtained for the six DNA concentrations to calculate the specific constitutive activity of the mutants. Slopes were determined by plotting TSH binding $(x$-axis) versus basal cAMP accumulation (y-axis) using the linear regression function of Graph Pad Prism 2.01 for Windows. The slope of the wtTSHR was set at 1 and slopes of the mutants were calculated according to this. The data for each of the constructs represent results from at least two independent experiments, each performed in duplicate.

FACS analysis Cells were detached from the dishes $48 \mathrm{~h}$ after transfection using $1 \mathrm{mM}$ EDTA and $1 \mathrm{mM}$ EGTA in PBS and transferred in Falcon 2054 tubes. Cells were washed once with PBS containing 0.1\% BSA and $0.1 \% \mathrm{NaN}_{3}$ before incubation with a 1:200 dilution of a mouse antihuman TSHR monoclonal antibody 2C11 (MAK 1281, Linaris, Wertheim-Bettingen; $10 \mu \mathrm{g} / \mathrm{ml}$ ) for $1 \mathrm{~h}$. The cells were washed twice and incubated at $4{ }^{\circ} \mathrm{C}$ for $1 \mathrm{~h}$ in darkness with 1:200 dilution of fluorescein-conjugated $\mathrm{F}(\mathrm{ab}) 2$ rabbit antimouse IgG (Serotec, Oxford, UK). Cells were washed twice and fixed with 1\% paraformaldehyde before FACS analysis (FACscan Becton Dickinson and Co., Franklin Lakes, NJ). Receptor expression was determined by fluorescence intensity, whereas the percentage of signalpositive cells corresponds to transfection efficiency.
Statistics Statistical analysis was carried out by oneway ANOVA, followed by Dunnett's Multiple Comparison Test using Graph Pad Prism 2.01 for Windows (not significant, $P>0.05$; significant, $P=0.01-0.05$; very significant, $P=0.001-0.01) . \chi^{2}$-test was used to compare the frequency of TSHR and Gs $\alpha$ mutations and the TSHR polymorphism in different regions.

\section{Results}

Identification of mutations, polymorphisms, and clonality All detected TSHR and Gs $\alpha$ gene mutations are summarized in Table 3. Over all, in 74 TTNs from 56 patients, $52(70.2 \%)$ TSHR mutations were found. All the mutations were heterozygous and detectable in adenoma tissues but not in the surrounding tissues. Most of the mutations are located in the transmembrane helix (TMH) 6 (Table 3). Of all detected mutations, 49 are known as constitutively active. Recently, one of them located at position $\mathrm{A} 428 \mathrm{~V}(\mathrm{GCT} \rightarrow \mathrm{GTT})$ in $\mathrm{TMH} 1$ (Table 3) has been described as a germline mutation (35). However, A428V has not been characterized so far. Three new TSHR mutations (A627V, I640K, and I486N) which have not been reported or characterized previously

Table 3 TSHR and Gs $\alpha$ gene mutations in the 74 toxic thyroid nodules (TTNs).

\begin{tabular}{|c|c|c|c|}
\hline $\begin{array}{l}\text { Amino acid } \\
\text { position and } \\
\text { substitution }\end{array}$ & $\begin{array}{c}\text { Base } \\
\text { substitution }\end{array}$ & $\begin{array}{l}\text { Mutation } \\
\text { frequency }\end{array}$ & $\begin{array}{c}\text { Mutation } \\
\text { position }\end{array}$ \\
\hline S281N & $\mathrm{AGC} \rightarrow \mathrm{AAC}$ & 1 & ECD \\
\hline $\mathrm{S} 281 \mathrm{~T}$ & $\mathrm{AGC} \rightarrow \mathrm{ACC}$ & 1 & ECD \\
\hline $\mathrm{A}^{4} 28 \mathrm{~V}^{\mathrm{a}}$ & $\mathrm{GCT} \rightarrow \mathrm{GTT}$ & 2 & 1st $\mathrm{TMH}$ \\
\hline M453T & $\mathrm{ATG} \rightarrow \mathrm{ACG}$ & 6 & 2nd $\mathrm{TMH}$ \\
\hline $1486 \mathrm{~F}$ & $\mathrm{ATC} \rightarrow \mathrm{TTC}$ & 2 & 1st ECL \\
\hline $1486 N^{b}$ & $\mathrm{ATC} \rightarrow \mathrm{AAC}$ & 1 & 1st ECL \\
\hline S505N & $\mathrm{AGC} \rightarrow \mathrm{AAC}$ & 1 & 3rd TMH \\
\hline L512Q & $\mathrm{CTG} \rightarrow \mathrm{CAG}$ & 2 & 3rd TMH \\
\hline L512R & $\mathrm{CTG} \rightarrow \mathrm{CGG}$ & 1 & 3rd TMH \\
\hline I568T & $\mathrm{ATC} \rightarrow \mathrm{ACC}$ & 1 & 2nd ECL \\
\hline D619G & $\mathrm{GAT} \rightarrow \mathrm{GGT}$ & 5 & 3rd ICL \\
\hline A623V & $\mathrm{GCC} \rightarrow \mathrm{GTC}$ & 5 & 3rd ICL \\
\hline $\mathrm{A} 627 \mathrm{~V}^{\mathrm{b}}$ & $\mathrm{GCT} \rightarrow \mathrm{GTT}$ & 1 & 6th TMH \\
\hline L629F & $\mathrm{TTG} \rightarrow \mathrm{TTC}$ & 2 & 6th TMH \\
\hline L629F & $\mathrm{TTG} \rightarrow \mathrm{TTT}$ & 1 & 6th TMH \\
\hline I630L & $\mathrm{ATC} \rightarrow \mathrm{CTC}$ & 1 & 6th TMH \\
\hline F631L & $\mathrm{TTC} \rightarrow \mathrm{TTA}$ & 2 & 6th TMH \\
\hline T632I & $\mathrm{ACC} \rightarrow \mathrm{ATC}$ & 8 & 6th TMH \\
\hline T632A & $\mathrm{ACC} \rightarrow \mathrm{GCC}$ & 2 & 6th TMH \\
\hline D633Y & $\mathrm{GAC} \rightarrow \mathrm{TAC}$ & 3 & 6th TMH \\
\hline D633H & $\mathrm{GAC} \rightarrow \mathrm{CAC}$ & 1 & 6th TMH \\
\hline P639S & $\mathrm{CCA} \rightarrow \mathrm{TCA}$ & 1 & 6th TMH \\
\hline $1640 K^{b}$ & $\mathrm{ATC} \rightarrow \mathrm{AAA}$ & 1 & 6th $\mathrm{TMH}$ \\
\hline V656F & $\mathrm{GTT} \rightarrow \mathrm{TTT}$ & 1 & 3rd ECL \\
\hline $\mathrm{R} 201 \mathrm{H}(\mathrm{Gs} \alpha)$ & $\mathrm{CGT} \rightarrow \mathrm{CAT}$ & 1 & \\
\hline
\end{tabular}

Over all, 52 (70.2\%) TSHR mutations were found in 74 TTNs from 56 patients.

${ }^{a}$ One of these has been reported recently, but not characterized so far. ${ }^{b}$ Three of these are novel mutations not reported or characterized so far. ECD, extracellular domain; ECL, extracellular loop; ICL, intracellular loop; $\mathrm{TMH}$, transmembrane helix. 
were also detected in this study. One of the new constitutively activating TSHR mutations is located at position $\mathrm{I} 486 \mathrm{~N}$ in the extracellular loop (ECL) 1 . The other two new mutations are located near the hot spot region in TMH 6 at position A627 (GCT $\rightarrow$ GTT; A627V) and I640 $($ ATC $\rightarrow$ AAA; I640K).

DNA samples without detectable TSHR gene mutations were also screened for constitutively activating Gs $\alpha$ mutations at exons 7 or 8. One heterozygous Gs $\alpha$ mutation located at position R201, leading to an exchange of arginine to histidine, was identified in a hot nodule.

In 12 patients $(21.4 \%)$, the polymorphism D727E at the intracellular cytoplasmic tail of the TSHR was found in the nodular tissue and also in the DNA extracted from the lymphocytes. In 11 patients, the polymorphism was heterozygous and 1 was found homozygous. This latter patient also carried the D633Y mutation, located in the sixth transmembrane domain of the TSHR.

Clonal origin was studied in 59 TTNs from 45 female patients using $\mathrm{X}$-chromosome inactivation. In this group, 38 patients with 48 nodules were heterozygous for the $(\mathrm{CAG})_{n}$-polymorphism in exon 1 of the human androgen receptor (HUMARA). Seven patients with eleven nodules were not informative for this polymorphism. Non-random X-chromosome inactivation was detected in 34 (70.9\%) of 48 cases, whereas the other 14 (29.1\%) showed random inactivation indicating a polyclonal origin. In the group of TTNs that contains a somatic mutation in the TSHR or Gs $\alpha, 26$ of $36(72.2 \%)$ cases showed non-random X-chromosome inactivation characterized by a loss of amplification for 1 allele after PCR from HpaII-digested DNA. In 10 of 36 $(27.8 \%)$ cases with a TSHR mutation, random $\mathrm{X}$ inactivation was detected. In the group of TTNs without detectable mutations in the TSHR or Gs $\alpha$, only 4 of 12 $(33.3 \%)$ cases showed random inactivation, 8 of 12 $(66.7 \%)$ toxic nodules without TSHR mutations showed non-random X-chromosome inactivation.

Prevalences of the TTNs with somatic mutations, clonality and $D 727 E$ polymorphism in the iodinedeficient or -sufficient regions In 74 TTNs, 52 (70.2\%) TSHR mutations were found. Contamination or sampling imprecisions are unlikely reasons for the detection of the same mutation in the 2 nodules of patients 10 as suggested by reanalysis of the samples. For patient 32, a sampling problem could not be definitely excluded. The prevalence of TSHR mutations was similar in the iodine-deficient UI, iodine sufficient, mixed and iodine deficient GP groups. Although the prevalence of TSHR mutations in the iodine-sufficient region $(73.7 \%)$ was slightly higher than in the iodine-deficient UI (70\%) and GP (64.3\%), the difference was not statistically significant $\left(x^{2}, 0.652 ; P, 0.884\right)$ (Table 4).

The polymorphism D727E at the intracellular cytoplasmic tail was present in $12(21.4 \%)$ patients.
Table 4 Prevalence of somatic TSHR and Gs $\alpha$ mutations in toxic thyroid nodules in iodine-sufficient and -deficient areas.

\begin{tabular}{lcccc}
\hline Mutation & $\begin{array}{c}\text { lodine } \\
\text { deficient } \\
\text { UI }\end{array}$ & $\begin{array}{c}\text { lodine } \\
\text { deficient } \\
\text { GP }\end{array}$ & $\begin{array}{c}\text { lodine } \\
\text { sufficient }\end{array}$ & Mixed \\
\hline $\begin{array}{c}\text { TSHR/Gs } \alpha \\
\text { Positive }\end{array}$ & $14(70 \%)$ & $9(64.3 \%)$ & $14(73.7 \%)$ & $16(76.2 \%)$ \\
$\begin{array}{c}\text { TSHR/Gs } \alpha \\
\text { Negative }\end{array}$ & $6(30 \%)$ & $5(35.7 \%)$ & $5(26.3 \%)$ & $5(23.8 \%)$ \\
\hline
\end{tabular}

The prevalence of TSHR mutations was similar in the iodine-deficient UI, iodine sufficient, iodine deficient GP, and mixed groups $\left(x^{2}: 0.652, P: 0.884\right)$. The results of the statistical tests for specific group differences were found non-significant (between iodine-deficient UI and iodine-sufficient groups $x^{2}$, $0.065 ; P, 0.798$, between iodine deficient GP and iodine-sufficient groups $x^{2}$, $0.337 ; P, 0.561)$. When iodine-deficient $\mathrm{UI}$ and iodine-deficient GP considered as one group, no statistical difference was found between iodine sufficient and (iodine-deficient UI+ iodine-deficient GP) groups ( $x^{2}: 0.51$ and $\left.P: 0.771\right)$.

The prevalence of polymorphism D727E was found to be $20 \%(3 / 15)$ in iodine-deficient UI, $21.4 \%(3 / 14)$ in iodine sufficient, $8.4 \%(1 / 12)$ in iodine deficient GP, and $33.4 \%(5 / 15)$ in the mixed groups. The prevalence of this polymorphism did not differ between groups $\left(x^{2}\right.$, 2.503; $P, 0.475)$.

Forty-eight cases were heterozygous for the $(\mathrm{CAG})_{n}$ in exon 1 of the HUMARA gene and 11 were not informative for the polymorphism. Non-random $\mathrm{X}$-chromosome inactivation was shown in 34 (70.9\%) of 48 cases, whereas the other 14 (29.1\%) showed random inactivation indicating polyclonal origin. The prevalances of clonal nodules were found to be $85.7 \%$ $(12 / 14)$ in the iodine-deficient UI group, $77.7 \%(7 / 9)$ in iodine-deficient GP group, $75 \%(9 / 12)$ in the iodinesufficient group, and $46 \%(6 / 13)$ in the mixed group. There was no statistically significant difference between the prevalences of nodules with clonality in the groups $\left(x^{2}, 5.644 ; P, 0.130\right)$ (Table 5).

Functional analysis of new mutations After transient transfection in COS-7 cells, functional characterization of the TSHR mutants was performed by the determination of cell surface expression, basal and bTSH-induced cAMP accumulation, as well as specific constitutive activity. Functional characteristics of all new somatic mutants are summarized in Table 6 .

A627V, I640K, and I486N were characterized by a cell surface expression in a range of 44-61\%, compared with the wt TSHR (set at $100 \%$ ), whereas A428V revealed the lowest expression with 25\%. However, all mutants caused constitutive activation (three- to sevenfold over wt TSHR basal). Slopes were determined to evaluate all mutants independently from their cell surface expression. The highest slope with 88.2 revealed mutant $\mathrm{A} 428 \mathrm{~V}$, followed by I640K with 14.6 , I486N with 6.7 , and A627V with 4.2 (Table 6). Activation of the mutated TSHRs showed a reduced cAMP response only for A627V and I640K. 
Table 5 Frequency of clonal or polyclonal origin of the toxic thyroid nodules in iodine-sufficient and -deficient areas.

\begin{tabular}{|c|c|c|c|c|c|c|}
\hline & \multicolumn{4}{|c|}{ Regions } & \multicolumn{2}{|c|}{ TSHR/Gs $\alpha$ mutation } \\
\hline & $\begin{array}{c}\text { Iodine-deficient } \\
\text { UI }\end{array}$ & $\begin{array}{c}\text { lodine-deficient } \\
\text { GP }\end{array}$ & Iodine-sufficient & Mixed & $\begin{array}{c}\text { TSHR/Gs } \alpha \\
\text { negative }\end{array}$ & $\begin{array}{l}\text { TSHR/Gs } \alpha \\
\text { positive }\end{array}$ \\
\hline $\begin{array}{l}\text { Number of informative } \\
\text { females studied }\end{array}$ & 14 & 9 & 12 & 13 & 12 & 36 \\
\hline Clonal origin & $12(85.7 \%)$ & 7 (77.7\%) & $9(75 \%)$ & $6(46 \%)$ & $8(66.7 \%)$ & $26(72.2 \%)$ \\
\hline Polyclonal origin & $2(14.3 \%)$ & $2(22.3 \%)$ & $3(25 \%)$ & $7(54 \%)$ & $4(33.3 \%)$ & $10(27.8 \%)$ \\
\hline
\end{tabular}

TSHR, thyroid stimulating hormone receptor; UI, urinary iodine; GP, goiter prevalence. There was no significant difference between the prevalences of nodules with clonality in the iodine-deficient UI, iodine sufficient, iodine-deficient GP and mixed groups ( $\left.x^{2}: 5.644 P: 0.130\right)$.

\section{Discussion}

Prevalences of somatic mutations of TTNs in relation to the iodine status Activating somatic mutations of the TSHR and Gs $\alpha$ have been described with different frequencies (Table 1). Apart from the sensitivity of the detection methods, the size of the TSHR region screened for mutations, the number of nodules examined, the quality of the tissue samples, and the differences in iodine supply are possible explanations for this variability of the prevalence of somatic TSHR mutations (1).

Therefore, this study determined the TSHR mutation frequency in TTNs using a very sensitive method (DGGE) covering exons 9 and 10 of the TSHR in regions of Turkey with sufficient or insufficient iodine supply and compared these results with the TSHR mutation frequencies from other countries with various degrees of iodine supply. This study also tried to answer the question of whether different degrees of iodine supply in Turkey, which were very likely present throughout the lifetime of the investigated patients, do influence the prevalence of TSHR mutations in hot nodules.

Table 6 Functional characterization of the previously reported (35) A428V and new somatic thyroid stimulating hormone receptor (TSHR) mutations. Data are given as mean \pm S.E.M. of three independent experiments, each carried out in duplicate.

\begin{tabular}{|c|c|c|c|c|}
\hline \multirow{3}{*}{$\begin{array}{l}\text { Transfected } \\
\text { construct }\end{array}$} & \multirow{3}{*}{$\begin{array}{c}\text { Cell surface } \\
\text { expression } \\
\text { FACS \% of } \\
\text { wt TSHR }\end{array}$} & \multicolumn{3}{|c|}{ cAMP accumulation } \\
\hline & & \multicolumn{2}{|c|}{ Relative to wt basal } & \multirow{2}{*}{$\begin{array}{c}\text { Fold over } \\
\text { wt basal } \\
\text { Slopes }\end{array}$} \\
\hline & & Stimulated & Basal & \\
\hline wt TSHR & ${ }_{100}^{\dagger}$ & $\begin{array}{c}1 \\
64+10^{\dagger}\end{array}$ & $15.1 \pm 0.6$ & $\begin{array}{c}1 \\
08+21^{\dagger}\end{array}$ \\
\hline $\begin{array}{l}\text { A428V } \\
1486 \mathrm{~N}\end{array}$ & $\begin{array}{l}25.1 \pm 0.6^{\prime} \\
60.9 \pm 1.3^{\dagger}\end{array}$ & $\begin{array}{l}6.4 \pm 1.0^{\prime} \\
7.1 \pm 1.2^{\dagger}\end{array}$ & $\begin{array}{l}13.6 \pm 2.4 \\
12.9 \pm 4.3\end{array}$ & $\begin{array}{r}88.2 \pm 2.1^{\dagger} \\
6.7 \pm 1.4^{\dagger}\end{array}$ \\
\hline A627V & $52.0 \pm 1.1^{\dagger}$ & $3.2 \pm 0.7^{*}$ & $8.2 \pm 0.8^{*}$ & $4.2 \pm 1.0^{\dagger}$ \\
\hline I640K & $44.2 \pm 1.6^{\dagger}$ & $5.9 \pm 0.4^{\dagger}$ & $8.0 \pm 0.4^{*}$ & $14.6 \pm 2.2^{\dagger}$ \\
\hline
\end{tabular}

For determination of cell surface expression, cAMP accumulation and linear regression analysis of constitutive activity as a function of TSHR expression (see Materials and methods) mutated TSHRs were cloned into the expression vector pSVL and transiently expressed in COS-7 cells. The wild-type (wt) receptor and empty $\mathrm{pSVL}$ vector were used as controls. Statistical analyses were carried out by one-way ANOVA, followed by Dunnett's Multiple Comparison Test using Graph Pad Prism 2.01 for Windows (not significant $P>0.05$; significant $\left({ }^{*}\right) P 0.01-0.05$; very significant $\left.\left({ }^{\dagger}\right) P 0.001-0.01\right)$.
From the 56 patients, 74 TTNs were examined and 52 (70.2\%) TSHR mutations were found. The mutations found in our study are distributed along the exons 9 and 10 of the TSHR (Table 3). All new TSHR mutations (A627V, I640K, and I486N) showed constitutive activity when transiently expressed in COS-7 cells (Table 6). Only 1 of the 74 nodules harbored a Gs $\alpha$ mutation (R201H).

Different frequencies of TSHR mutations were reported in different countries ranging from 8 to $77 \%$ $(7,9,11,15,16,18)$ in Italy (median urine iodine level, 55-122 mcg/l), 82\% in Belgium (12) (median UI level, $80 \mathrm{mcg} / \mathrm{l}), 48-57 \%$ in Germany $(13,19)$ (median UI level, $88-148 \mathrm{mcg} / \mathrm{l}$ ), and $40 \%$ in Greece (21) (median UI level, $84-160 \mathrm{mcg} / \mathrm{l})$. On the other hand, only somatic TSHR mutations were found in 1 of 45 TTNs in Japan (median UI level, 296-728 mcg/l), a country with high iodine supply (10). The frequencies of TSHR mutations were described to be high in Italy $(64,77$, $70 \%)(7,15,18)$ and Belgium $(82 \%)(12)$ and slightly lower in Germany $(48,57 \%)(13,19)$ and Greece $(40 \%)$ (21). However, apart from this possible relation of the TSHR mutation frequency to the slight differences in iodine supply, the frequency of the TSHR mutation was also high in those studies in which exons 9 and 10 were screened by direct sequencing or DGGE in fresh-frozen tissues (12-15, 18-19).

In this study, there were no significant differences regarding the TSHR mutation frequencies between iodine-sufficient and -deficient regions (Table 4). The prevalence of somatic TSHR mutations in TTNs was $70 \%$ in iodine-deficient UI, $73.7 \%$ in iodine sufficient, $64.3 \%$ in iodine-deficient GP, and $76.2 \%$ in mixed regions respectively. There was no statistically significant difference between the prevalence of mutations in iodine-deficient UI (70\%), iodine deficient GP (64.3\%), iodine sufficient $(73.7 \%)$, and mixed $(76.2 \%)$ groups. This suggests that the etiology of TTNs in both iodinedeficient and -sufficient areas predominantly involves mutagenesis of the TSHR. Constitutively activating TSHR mutations seem to be the most frequent molecular event independent of the status of iodine supply. This does not contradict evidence that deficient iodine supply increases the frequency of nodular transformation (36), since our sample of patients with TTNs does not allow us to infer such a frequency. 
It rather suggests that constitutive activation of the cAMP cascade is a prerequisite for TTNs and is most frequently achieved through TSHR mutagenesis irrespective of the iodine status.

Our patients were classified as iodine deficient, sufficient, or mixed group based on published UI excretion and endemic goiter prevalence (26-32). We are aware that this approach might be prone to a certain percentage of misclassification of patients (3739). However, the alternative approach to using individual spot UI values is likely to be highly variable over time (40). Seasonal, diurnal, and day-to-day variations of UI excretions have been reported (41). Therefore, individual UI determinations are unreliable as an indicator for an individual's iodine status. However, most important, it would be impossible to observe iodine-deficient patients for many years without suggesting them to use iodized salt. Therefore, the use of published UI excretion or goiter population screening data in areas with stable social and economic circumstances and low mobility (42) appears as the most reliable and feasible basis for an examination of the possible influence of iodine status on the TSHR mutation frequency in hot nodules.

The TSHR mutation frequency of all subgroups in this study is higher than that in the recent study from Japan with 40\% (20) and higher compared with other studies in Germany $(48,57 \%)(13,19)$ or Greece (40\%) (21) and Italy $(64,70 \%)(7,18)$, examining at least exons 9 and 10. Some of the variability of the TSHR mutation frequency might be attributable to methodological differences, for example, sequencing $(8,11,14,20-21)$ versus DGGE (19) as previously shown by Trültzsch et al. who could detect 6 of the 43 somatic TSHR mutations only with DGGE, but not direct sequencing of the tissue DNA. This might have obscured some of the possible iodine status-related differences. However, also the comparison of this study with the other largest hot nodule group, which both examined with the same sensitive method (DGGE) shows differences for TSHR mutation frequencies (70.2 vs $57 \%$, but not significant $\left.x^{2}, 3.31 ; P>0.05,19\right)$ which are of a similar magnitude to the above differences for patients with a similar iodine status (70.2 vs $40 \%$ for Greece, $x^{2}$, 9.08; $\left.P<0.01,21\right)$, (70.2 vs $70 \%$ for Italy $\left.x^{2}, 0.020, P>0.05,18\right)$ and $(70.2$ vs $82 \%$ for Belgium, $\left.x^{2}, 1.15, P>0.05,12\right)$. Given the methodological differences, imprecisions regarding the lifelong iodine status of the patients and the limited numbers of hot nodules samples examined, it is therefore very likely that we are presently unable to detect any significant differences in somatic TSHR mutation frequencies related to the iodine status. However, it could also be possible that the relatively small differences in UI within Europe are a reason for this somatic TSHR mutation frequency variability among European countries, since the association of large differences in hyperthyroidism (due to thyroid autonomy) with small differences in iodine intake has been reported (43).

We found that most of the TTNs (26 of 36, 72.2\%) containing a TSHR or Gs $\alpha$ mutation were of monoclonal origin. In line with previous studies reporting non-random X-chromosome inactivation in 79 and $70 \%$ respectively $(19,34)$, these results demonstrate that TTNs with a somatic mutation in the TSHR are predominantly monoclonal. In the present study, ten (27.8\%) mutation-positive nodules showed polyclonal origin. For the mutation-positive nodules, a frequency of $100 \%$ of clonal origin should be reached. However, due to the limited sensitivity of the assay, contamination by polyclonal cells from blood or by connective tissue and unaffected cells will lower the chance to get this $100 \%$ (34). Moreover, the error rate of the assay is around $5-10 \%$ (34). Most of the TTNs (8/12, 66.7\%) without a mutation were also monoclonal. Therefore, mutations in other candidate genes of the cAMP signal transduction pathway might play a role in these monoclonal TTNs without TSHR mutations. The most relevant finding is the similar frequency of a clonal origin for both iodine-deficient UI $(85.7 \%)$, GP $(77.7 \%)$ and iodine-sufficient regions $(75 \%)$. This also supports the conclusion drawn from the somatic mutation frequency, which is $73.7 \%$ for the iodinesufficient regions and 70 and $64 \%$ for the iodinedeficient UI and GP regions respectively. Both these findings suggest that TTNs in both iodine-deficient and -sufficient areas predominantly arise from aberrant growth of a single cell. In the hot nodules of some patients (e.g. 10 and 32), we detected somatic TSHR mutations which indicate a neoplastic growth in combination with results of the clonality assay that suggest a polyclonal origin. This contradiction very likely stems from differences in the sensitivity of the methods used for clonal analysis and detection of mutations. The PCR-based clonality assay would indicate a polyclonal origin even if the tumor tissue is monoclonal when contamination with non-tumor tissue is more than about 30\% (34). With DGGE, a mutation in the TSHR is still detectable when contamination is more than $90 \%$ (44). The cases where a somatic TSHR mutation was detected but $\mathrm{X}$-chromosome analysis indicates polyclonality are very likely cases with a higher degree of contamination with blood, connective, and, surrounding healthy tissue.

Taken together, this study demonstrates that the frequency of somatic TSHR mutations in hot nodules is actually high in Turkey without a significant difference between iodine-deficient and -sufficient regions. Moreover, the frequency of a monoclonal origin of TTNs is also high. Our results suggest that within the limitation discussed above, the proportion of neither TSHR mutations nor that monoclonal origin of TTNs is related to the iodine supply in the diet. 


\section{Acknowledgements}

We thank Mrs Elisabeth Peter for her excellent technical assistance. This work was supported by a DAAD scholarship to $\mathrm{R} \mathrm{B}$, a grant from the Deutsche Forschungsgemeinschaft (DFG/Pa423/10-1) and the Deutsche Krebshilfe (106542) and the Interdisciplinary Center for Clinical Research at the Faculty of Medicine of the University of Leipzig (Projects B20, Z03).

\section{References}

1 Krohn K, Fuhrer D, Bayer Y, Eszlinger M, Brauer V, Neumann S \& Paschke R. Molecular pathogenesis of euthyroid and toxic multinodular goiter. Endocrine Reviews 200526 504-524.

2 Krohn K \& Paschke R. Clinical Review 133. Progress in understanding the etiology of thyroid autonomy. Journal of Clinical Endocrinology and Metabolism 200186 3336-3343.

3 Corvilain B. The natural history of thyroid autonomy and hot nodules. Annals of Endocrinology (Paris) 200364 17-22.

4 Lyons J, Landis CA, Harsh G, Vallar L, Grunewald K, Feichtinger H, Duh QY, Clark OH, Kawasaki E, Bourne HR \& Mc Cormick F. Two G protein oncogenes in human endocrine tumors. Science 1990249 655-659.

5 O'Sullivan C, Barton CM, Staddon SL, Brown CL \& Lemoine NR. Activating point mutations of the $g s p$ oncogene in human thyroid adenomas. Molecular Carcinogenesis 1991 4 345-349.

6 Parma J, Duprez L, Van Sande J, Cochaux P, Gervy C, Mockel J, Dumont J \& Vassart G. Somatic mutations in the thyrotropin receptor gene cause hyperfunctioning thyroid adenomas. Nature 1993365 649-651.

7 Porcellini A, Ciullo I, Laviola L, Amabile G, Fenzi G \& Avvedimento VE. Novel mutations of thyrotropin receptor gene in thyroid hyperfunctioning adenomas. Rapid identification by fine needle aspiration biopsy. Journal of Clinical Endocrinology and Metabolism 199479 657-661.

8 Paschke R, Tonacchera M, Van Sande J, Parma J \& Vassart G. Identification and functional characterization of two new somatic mutations causing constitutive activation of the thyrotropin receptor in hyperfunctioning autonomous adenomas of the thyroid. Journal of Clinical Endocrinology and Metabolism 199479 1785-1789.

9 Russo D, Arturi F, Wicker R, Chazenbalk GD, Schlumberger M, DuVillard JA, Caillou B, Monier R, Rapoport B, Filetti S \& Suarez HG. Genetic alterations in thyroid hyperfunctioning adenomas. Journal of Clinical Endocrinology and Metabolism 1995 80 1347-1351.

10 Takeshita A, Nagayama Y, Yokoyama N, Ishikawa N, Ito K, Yamashita T, Obara T, Murakami Y, Kuma K \& Takamatsu J. Rarity of oncogenic mutations in the thyrotropin receptor of autonomously functioning thyroid nodules in Japan. Journal of Clinical Endocrinology and Metabolism 199580 2607-2611.

11 Russo D, Arturi F, Suarez HG, Schlumberger M, Du Villard JA, Crocetti U \& Filetti S. Thyrotropin receptor gene alterations in thyroid hyperfunctioning. Journal of Clinical Endocrinology and Metabolism 199681 1548-1551.

12 Parma J, Duprez L, Van Sande J, Hermans J, Rocmans P, Van Vliet G, Costagliola S, Rodien P, Dumont JE \& Vassart G. Diversity and prevalence of somatic mutations in the thyrotropin receptor and Gs alpha genes as a cause of toxic thyroid adenomas. Journal of Clinical Endocrinology and Metabolism $1997822695-2701$.

13 Fuhrer D, Holzapfel HP, Wonerow P, Scherbaum WA \& Paschke R. Somatic mutations in the thyrotropin receptor gene and not in the Gs alpha protein gene in 31 toxic thyroid nodules. Journal of Clinical Endocrinology and Metabolism 199782 3885-3891.

14 Holzapfel HP, Fuhrer D, Wonerow P, Weinland G, Scherbaum WA \& Paschke R. Identification of constitutively activating somatic thyrotropin receptor mutations in a subset of toxic multinodular goiters. Journal of Clinical Endocrinology and Metabolism $1997 \mathbf{8 2}$ 4229-4233.

15 Tonacchera M, Chiovato L, Pinchera A, Agretti P, Fiore E, Cetani F, Rocchi R, Viacava P, Miccoli P \& Vitti P. Hyperfunctioning thyroid nodules in toxic multinodular goiter share activating thyrotropin receptor mutations with solitary toxic adenoma. Journal of Clinical Endocrinology and Metabolism $1998 \mathbf{8 3} 492-498$.

16 Tassi V, Di Cerbo A, Porcellini A, Papini E, Cisternino C, Crescenzi A, Scillitani A, Pizzuti A, Ratti A, Trischitta V, Avvedimento VE, Fenzi G \& De Filippis V. Screening of thyrotropin receptor mutations by fine-needle aspiration biopsy in autonomous functioning thyroid nodules in multinodular goiters. Thyroid $19999353-357$.

17 Krohn K, Wohlgemuth S, Gerber H \& Paschke R. Hot microscopic areas of iodine - deficient euthyroid goiters contain constitutively activating TSH receptor mutations. Journal of Pathology 2000192 37-42.

18 Tonacchera M, Agretti P, Chiovato L, Rosellini V, Ceccarini G, Perri A, Viacava P, Naccarato AG, Miccoli P, Pinchera A \& Vitti P. Activating thyrotropin receptor mutations are present in non-adenomatous hyperfunctioning nodules of toxic or autonomous multinodular goiter. Journal of Clinical Endocrinology and Metabolism $2000 \mathbf{8 5} 2270-2274$.

19 Trulzsch B, Krohn K, Wonerow P, Chey S, Holzapfel HP, Ackermann F, Fuhrer D \& Paschke R. Detection of thyroidstimulating hormone receptor and Gsalpha mutations: in 75 toxic thyroid nodules by denaturing gradient gel electrophoresis. Journal of Molecular Medicine 2001 78 684-691.

20 Vanvooren V, Uchino S, Duprez L, Costa MJ, Vandekerckhove J, Parma J, Vassar G, Dumont JE, Van Sande J \& Noguchi S. Oncogenic mutations in the thyrotropin receptor of autonomously functioning thyroid nodules in the Japanese population. European Journal of Endocrinology 2002147 287-291.

21 Georgopoulos NA, Sykiotis GP, Sgourou A, Papachatzopoulou A, Markou KB, Kyriazopoulou V, Papavassiliou AG \& Vagenakis AG. Autonomously functioning thyroid nodules in a former iodinedeficient area commonly harbor gain-of-function mutations in the thyrotropin signaling pathway. European Journal of Endocrinology $2003149287-292$.

22 Gozu H, Avsar M, Bircan R, Sahin S, Deyneli O, Cirakoglu B \& \&Akalin S. Mutations in the thyrotropin receptor signal transduction pathway in the hyperfunctioning thyroid nodules from multinodular goiters: a study in the Turkish population. Endocrine Journal $2005 \mathbf{5 2}$ 577-585.

23 www3.who.int/whosis/micronutrient. WHO Survey: iodine status worldwide; WHO global database on iodine deficiency Geneva, 2004.

24 Vitti P, Pinchera A, DeLange F \& Moiner B. Europe is still iodine deficient. IDD Newsletter 20028 51-55.

25 Zimmermann MB, Ito Y, Hess SY, Fujieda K \& Molinari L. High thyroid volume in children with excess dietary iodine intakes. American Journal of Clinical Nutrition 200581 840-844.

26 Erdogan G, Erdogan MF, Emral R, Bastemir M, Sav H, Haznedaroglu D, Ustundag M, Kose R, Kamel N \& Genc Y. Iodine status and goiter prevalence in Turkey before mandatory iodization. Journal of Endocrinological Investigation $2002 \mathbf{2 5}$ 224-228.

27 Gür E, Ercan O, Can G, Akku S, Güzelyüz I, Çiftçili S, Arvas A \& Ilter O. Prevalence and iodine deficiency among school children. Journal of Topical Pediatrics $2003 \mathbf{4 9} 168-171$.

28 Akpinar D, Tanakol R, Boztepe H, Abbasoglu S, Toker G \& Alagol F. The frequency of goitre and the levels of urinary lodine among highschool students before the official ıodination of salt in Turkey. Istanbul Universitesi Tip Fakultesi Dergisi 200265 176-181 (in Turkish).

29 Beykal S. Kocaeli ili merkez ilçesinde içme sularındaki iyot düzeyi ile ilkokul çocuklarında iyot eksikliği ve guatr sıklığının karşılaştırılması (the correlation between iodine level in the drinking water in the Central region of Kocaeli and frequency of 
endemic goiter at school children, in Turkish). Istanbul: IU Cerrahpasa Tip Fakultesi Medikal Ekoloji ve Hidroklimatoloji ABD, 1999 (Doktora tezi).

30 Erdogan MF. Ötiroid guatr, diğer iyot eksikliği hastalıkları ve Türkiye'nin iyot durumu. In Kologlu Endokrinoloji Temel ve Klinik, 2 edn, pp 200-210. Ed. G Erdogan. Ankara: MN Medical \& Nobel, 2005.

31 Murat M. Sivas il merkezinde okul çağı çocuklarında iyot eksikliği ve guatr prevelansı (iodine deficiency disorders and goiter prevalence at school age children in Sivas, in Turkish). Adana: Adana Çukurova Universitesi Ic Hastaliklari ABD, 2000 (Doktora tezi).

32 Hatemi H \& Urgancioglu H. In Iodine Deficiency in Europe: a Continuing Concern, pp 427-430. Eds Delange, JT Dunn \& D Glinoer. New York: Plenum Press, 1993.

33 IDD News Letter $19941037-41$.

34 Krohn K, Fuhrer D, Holzapfel HP \& Paschke R. Clonal origin of toxic thyroid nodules with constitutive activating thyrotropin receptor mutations. Journal of Clinical Endocrinology and Metabolism 199883 130-134.

35 Borgel K, Pohlenz J, Koch HG \& Bramswig JH. Long-term carbimazole treatment of neonatal nonautoimmune hyperthyroidism due to a new activating TSH receptor gene mutation (Ala428Val). Hormone Research 200564 203-208.

36 Belfiore A, La Rosa GL, Padova G, Sava L, Ippolito O \& Vigneri R. The frequency of cold thyroid nodules and thyroid malignancies in patients from an iodine-deficient area. Cancer $1997 \mathbf{1 5}$ 3096-3102.

37 Saggiorato E, Mussa A, Sacerdote C, Rossetto R, Arecco F, Origlia C, Germano L, Deandreis D \& Orlandi F. Piemonte Goiter Study Committee. Thyroid volume and urinary iodine excretion in the schoolchild population of a Northwestern Italian sub-Alp metropolitan area. Journal of Endocrinological Investigation 2004 27 516-522.
38 Brauer VF, Brauer WH, Fuhrer D \& Paschke R. Iodine nutrition, nodular thyroid disease, and urinary iodine excretion in a German university study population. Thyroid $200515364-370$.

39 Demirel F, Ozer T, Gurel A, Acun C, Ozdemir H, Tomac N \& Unalacak M. Effect of iodine supplementation on goiter prevalence among the pediatric population in a severely iodine deficient area. Journal of Pediatric Endocrinology and Metabolism 200417 73-76.

40 www.cdc.gov/nccdphp/dnpa/immpact/micronutrient_facts.htm. Assessment of Iodine Deficiency Disorders and Monitoring their Elimination: A Guide for Programme Managers 2nd edn. WHO/ UNICEF/ICCIDD 2001.

41 Rasmussen LB, Ovesen L \& Christiansen E. Day-to-day and withinday variation in urinary iodine excretion. European Journal of Clinical Nutrution 199953 401-407.

42 Andersson M, Takkouche B, Egli I, Allen HE \& de Benoist B. Current global iodine status and progress over the last decade towards the elimination of the iodine deficiency. Bulletin of the World Health Organization 200583 518-525.

43 Bulow Pedersen I, Knudsen N, Jorgensen T, Jorgensen H, Perrild H, Ovesen L \& Laurberg P. Large differences in incidences of overt hyper- and hypothyroidism associated with a small difference in iodine intake: a prospective comparative register-based population survey. Journal of Clinical Endocrinology and Metabolism $2002 \mathbf{8 7}$ 4462-4469.

44 Trulzsch B, Krohn K, Wonerow P \& Paschke R. DGGE is more sensitive for the detection of somatic point mutations than direct sequencing. Biotechniques 199927 266-268.

Received 7 April 2006

Accepted 14 July 2006 